\title{
Yes We Can, But How? Women's Representation in Global Business
}

\author{
Amanda Budde-Sung, U.S. Air Force Academy, USA \\ Amanda Bullough, University of Delaware, USA \\ Tugba Kalafatoglu, ESADE Business School, Spain \\ Fiona Moore, University of London, UK
}

Research on women in international business and management matters for many reasons. Achieving global gender parity in workforce participation could add $\$ 12$ trillion to global GDP by 2025 (McKinsey Global Institute, 2015). Having more women on corporate boards and in top management often leads to stronger financial performance (e.g., Conyon \& He, 2017; Dezsö \& Ross, 2012). Female business leaders are associated with lower levels of corruption and bribery (e.g., Breen et al, 2017); have different managerial techniques (e.g., Keeves, Westphal, \& McDonald, 2017); are willing to pursue entrepreneurial ventures in areas their male counterparts fear (e.g., Bullough \& Renko, 2017); and have different preferred leadership prototypes (e.g., Paris et al, 2009). Around the globe, researchers are exploring how to close the gender gap and better harness the opportunities that gender differences can bring.

Many firms have rules in place, either intra-company rules, or external legal rules, that prevent gender discrimination. In the pursuit of the benefits that gender diversity can bring, many countries have passed laws implementing quotas for women on corporate boards, and yet women remain woefully underrepresented on corporate boards around the world, even in countries that have enacted those laws. Some countries have generous maternity leave policies, and yet a significant motherhood pay gap persists across the globe, where women's earnings decrease with each child, and men's earnings tend to increase with the arrival of children. Even after each of the G20 countries supported addressing the issue of gender discrimination at the 2014 G20 conference in Australia, women's wages continue to lag behind men's wages in all of the G20 countries. The same problems are faced at the firm level. When firms adopt wage transparency policies, many are often shocked to find that gender-based pay gaps persist in their own firms. Clearly, governmental and company-level policymakers wish to take effective action, but they appear to lack clear policies to effectively do so.

This article highlights some benefits that greater gender diversity in firms can offer and recommends policies that can be implemented to more effectively achieve those benefits. Four key areas where greater gender diversity can make a difference, namely corporate governance, leadership, entrepreneurship and innovation, are explored before examining policy ideas that can encourage gender diversity in the workplace and senior management.

\section{Corporate Governance}

Studies in corporate governance have shown that companies whose boards have greater representation of women fare better: they have higher profits, lower employee turnovers, fewer ethical violations, and they pursue greener, more environmentally friendly policies. All firms would like to achieve these goals, but many fail to do so, despite gender-advancing policies. This disconnect may be due to a focus on the outputs - the number of women on boards - instead of the inputs, which is a strong pipeline of female workers who may eventually become board members. In other words, the problem did not begin with the board itself, but rather, with the hiring and promotion processes at the entry- and mid-levels. Indeed, policy analysts who 
study this issue have suggested that a stronger pipeline of qualified women would result in greater gender diversity on boards, thus allowing firms to enjoy the concurrent benefits of that diversity. To build a pipeline of female talent from which new board members may be recruited, firms can encourage more women to participate in company leadership in multiple areas and levels.

\section{Leadership}

Recent studies indicate that companies with female CEOs tend to face more challenges from activist investors. While this bias is disconcerting when viewed from a gender equality perspective, it does mean that activist investors expect female-led companies to have stronger foundations and better cohesiveness than male-led companies. Companies with more women in top leadership roles tend to have better financial performance and lower employee turnover, but to achieve these results, women need representation in firms beyond tokenism. A study by the Peterson Institute for International Economics indicated that firms begin to reap benefits of gender diversity when at least $30 \%$ of a firm's leaders are female (Dezsö \& Ross, 2012). The recommendation for firms is to develop a pipeline of female leaders by encouraging more women to put their hands up for higher-level leadership positions, and by providing more leadership development opportunities for women to equip them with the necessary tools to serve in those roles. Specific mentoring is also recommended here, with mentors supporting female employees as they pursue higher opportunities within the company.

\section{Entrepreneurship}

Female-led start-ups consistently outperform male-led startups. A 2013 study found that women-led entrepreneurial teams have a $35 \%$ higher return on investment than do allmale entrepreneurial teams (Garaizar, 2016). A 2018 Boston Consulting Group study found that female-led ventures produce higher revenues than do all-male ventures, but that they receive far less venture capital (VC) funds than do all-male teams (Boston Consulting Group, 2018). Indeed, the gender bias in venture capital is widely documented, so the major question remains: if women are a better bet than men are in entrepreneurial ventures, then why don't they receive more VC funding? A proposed solution is for big VC firms to hire more women in decision-making roles. Since VC firms hire and promote from within their own networks, the network effect is significant. The gender bias in VC is often not a distrust of female-led startups; it is that the large funds tend to be led and staffed by men, and their networks overwhelmingly match $\mathrm{VC}$ funding to male entrepreneurs. Women need, therefore, to become more of a presence in VC firms, and to network more with the large funders. Policies at VC firms can help overcome gender bias by developing women-led funds and by hiring more female decision-makers. Governmental policymakers can also help, by demanding transparency and gender reporting in VC funding. Governmental policies that require wage transparency have resulted in greater awareness of, and thus, greater efforts to correct, gender-based wage disparities. Similar transparency policies in the VC industry could have similar results, creating win-win scenarios, with more female-led ventures receiving greater funding, and more $\mathrm{VC}$ funds earning better returns.

Beyond the world of formal entrepreneurship, women-led entrepreneurial ventures are growing in the informal economy. This trend is often attributed to a lack of support for female-led businesses in the formal economy. The trend is a lose-lose scenario: governments miss out on taxation and regulation opportunities; other firms miss out on opportunities to engage with these female-led firms; and the female-led firms themselves are exposed to the risks of the unregulated informal economy. Suggestions to bring more women entrepreneurs from the informal economy to the formal economy so that all potential stakeholders may benefit include focused policies to encourage female entrepreneurship; public support for female entrepreneurship from top leadership of VC firms; and facilitating greater access to VC networks for women entrepreneurs. Some evidence suggests that women entrepreneurs may also be less intimidated by risky environments than their male counterparts, and may pursue more opportunities in dangerous areas where their male counterparts fear to tread (Bullough \& Renko, 2017). This courageous attitude provides female-led startups market opportunities and provides needed goods and services to underserved markets. Suggestions for how to support and increase female-led startups in dangerous locations include public support for female businesspeople; establishment and facilitation of networks for female entrepreneurs; and matching investment money and resources to female-led startups that need it.

\section{Innovation}

The global world of intellectual property (IP) has gender biases as well. Male scientists and engineers are more than twice as likely to file for patents on their innovations than women are. Women-only patent applications are more likely to be rejected by the US Patent and Trademark Office, and when they are approved, they are more likely to be required to provide greater specificity in the details, thus reducing the patents' commercial value (Jensen, Kovacs, \& Sorenson, 2018). This gender disparity is important, given that scientific and technical patents tend to create a strong multiplier effect, sustaining many jobs and providing significant stimulus to local economies. Furthermore, in patents, women's names are often included in publications related to the patent, but not in the patent application itself, suggesting that women are being left out of an important aspect of the innovation cycle. Many studies have shown that increasing IP protection among women improves their partic- 
ipation in the economy and encourages greater female entrepreneurship, thus allowing the economy itself to benefit from greater female participation. Removing gender biases in the development and protection of intellectual property will stimulate more female entrepreneurship, greater economic development, and create more jobs in the world economy. To help achieve these benefits, the World Intellectual Property Office (WIPO) adopted a Gender Equality policy in 2014, with stated goals of promoting greater female empowerment and equality in intellectual property. Suggestions in this policy include ensuring that advisory bodies to WIPO are comprised of both men and women; fostering and nurturing female networks to educate women about IP protection processes and strategies; and incorporating gender-sensitive performance indicators.

\section{Policy Suggestions}

A common theme throughout these suggestions, highlighted in Table 1, is for firms and governmental policymakers to facilitate networks for women. Much business activity centers around relationships, and firms miss out on benefits from re- lationships that underrepresent women. Firms would like to make more money; VCs would like to make higher returns; and governments would like to encourage greater female participation in business, but achieving these benefits requires targeted efforts across firms, VCs and governments. In their recent book, Bullough, Hechavarría, Brush, and Edelman (2019) recommend specific and practical programs, policies, and practices that can be implemented at the organizational and governmental levels to increase women's roles in business. Given the lack of networks and relationships among businesswomen, formal networking opportunities should be created and fostered. These networking opportunities need to include mentoring options as well as connecting women to sources of financing. A second recommendation that may help firms and governments close gender gaps is to focus on pathways and inputs, rather than outputs. In other words, it is important to look not only at how many female CEOs there are, but also how many top female managers are in the potential pipelines for those roles. If women are underrepresented in these pipelines, then policymakers can develop policies and resources to encourage more women to make themselves available for these roles. A third recommendation is monitoring. Firms are often

Table 1. Policy Suggestion Themes

\begin{tabular}{|c|c|c|c|c|}
\hline Research Area & Female Representation & Challenges & Implications for Companies & Implications for Policymakers \\
\hline $\begin{array}{l}\text { Corporate } \\
\text { Governance }\end{array}$ & $\begin{array}{l}\text { Firms with more women on } \\
\text { boards perform better. }\end{array}$ & $\begin{array}{l}\text { Failures in recruitment and } \\
\text { development, and the linked } \\
\text { failure to develop a female } \\
\text { leadership pipeline. }\end{array}$ & $\begin{array}{l}\text { Need to develop pipelines } \\
\text { to encourage, develop, and } \\
\text { promote female talent. }\end{array}$ & $\begin{array}{l}\text { Create programs to identify } \\
\text { future women leaders and } \\
\text { encourage their development. }\end{array}$ \\
\hline Leadership & $\begin{array}{l}\text { Companies with greater } \\
\text { female representation at } \\
\text { top levels perform better } \\
\text { and have better work } \\
\text { environments. }\end{array}$ & $\begin{array}{l}\text { Few female leaders; female } \\
\text { leaders are more likely to } \\
\text { face challengers and greater } \\
\text { scrutiny. }\end{array}$ & $\begin{array}{l}\text { Develop opportunities for } \\
\text { women to pursue leadership } \\
\text { roles. Include greater numbers } \\
\text { of women in top roles, and } \\
\text { create more female-friendly } \\
\text { corporate environments. }\end{array}$ & $\begin{array}{l}\text { Encourage female networks } \\
\text { and mentorship opportunities. } \\
\text { Establishing formal networks in } \\
\text { the absence of informal ones has } \\
\text { proven effective. Ingrain a culture } \\
\text { of inclusivity that weeds out bias. }\end{array}$ \\
\hline Entrepreneurship & $\begin{array}{l}\text { Female led startups } \\
\text { outperform male led startups, } \\
\text { although there are far fewer } \\
\text { female-led startups. }\end{array}$ & $\begin{array}{l}\text { Less available VC funding; } \\
\text { less funding overall; female- } \\
\text { led startups more likely in } \\
\text { risky and informal areas. }\end{array}$ & $\begin{array}{l}\text { More VC funding for women } \\
\text { entrepreneurs; Establish } \\
\text { more formal networking } \\
\text { opportunities for women. }\end{array}$ & $\begin{array}{l}\text { Financial and infrastructure } \\
\text { support for female startups; } \\
\text { encourage networks opportunities } \\
\text { for women. Increase exposure of } \\
\text { female entrepreneurs to VC funds } \\
\text { and more VC funding to female } \\
\text { entrepreneurs. }\end{array}$ \\
\hline Innovation & $\begin{array}{l}\text { Female underrepresentation } \\
\text { in IP protection. }\end{array}$ & $\begin{array}{l}\text { Women not filing for legal IP } \\
\text { protection, and/or receiving } \\
\text { greater scrutiny, and more } \\
\text { rejections, when they do. } \\
\text { Women dropping out of the } \\
\text { innovation cycle prior to } \\
\text { patent application. }\end{array}$ & $\begin{array}{l}\text { Educate female innovators } \\
\text { about IP protection systems. } \\
\text { Facilitate networks for female } \\
\text { innovators to share knowledge } \\
\text { about innovation protection } \\
\text { and commercialization. } \\
\text { Encourage women to } \\
\text { remain active in the entire } \\
\text { innovation cycle, from } \\
\text { conception to protection and } \\
\text { commercialization. }\end{array}$ & $\begin{array}{l}\text { Develop female networks and } \\
\text { increase understanding of } \\
\text { IP protection. Create formal } \\
\text { programs to assist women in } \\
\text { protecting innovations for } \\
\text { commercial viability. Review } \\
\text { registration requirements to } \\
\text { ensure gender neutrality among } \\
\text { IP examiners. }\end{array}$ \\
\hline
\end{tabular}


surprised at gender imbalances within their organizations, as are the governments that govern them. Many countries profess to believe in gender equality, but only six countries actually grant women equal legal working rights to men (World Bank, 2019). Monitoring can alert leaders to gender imbalances. Finally, focused action is needed. The benefits of gender diversity do not happen simply because people hope they will. Recognizing and focusing on the problem, as well as acknowledging that solutions may not be as simple as "hire more women," is a necessary step.

More research is needed to help firms realize the benefits of gender diversity. It is not enough to say that possible benefits exist; the current gaps between goals and reality regarding gender indicate that the pathways to reaping the benefits of greater gender equality remain elusive. Policymakers and practitioners alike need clearer ways to bring about greater female representation in global business. Women represent slightly more than half of the world's population, women have unique challenges and contexts, and women bring unique benefits when they engage in global business. The time has come to investigate those challenges and contexts. International business community, consider this your call.

\section{References}

Boston Consulting Group. 2018. Women-owned startups deliver twice as much per dollar invested as those founded by men. June 6, https://www.bcg.com/publications/2018/why-women-owned-startups-are-better-bet.aspx.

Breen, M., Gillanders, R., McNulty, G., \& Suzuki, A. 2017. Gender and corruption in business. Journal of Development Studies, 53(9): 1486-1501.

Bullough, A., \& Renko, M. 2017. A Different Frame of Reference: Entrepreneurship and Gender Differences in the Perception of Danger. Academy of Management Discoveries, 3(1): 21-41.

Bullough, A., Hechavarria, D., Brush, C., \& Edelman, L. (Eds) 2019. Programs, Policies, \& Practices around High-Growth Women's Entrepreneurship. Cheltenham: Edward Elgar Publishing.

Conyon, M. J. \& He, L. 2017. Firm performance and boardroom gender diversity: A quantile regression approach. Journal of Business Research, 79: 198-211.

Dezsö, C. L., \& Ross, D. G. 2012. Does female representation in top management improve firm performance? A panel data investigation. Strategic Management Journal, 33(9): 1072-1089.

Garaizar, J. 2016. The rising tide: a learning-by-investing initiative to bridge the gender gap. Kauffman Fellows Report, vol. 7

Jensen, K., Kovacs, B., \& Sorenson, O. 2018. Gender differences in obtaining and maintaining patent rights. Nature Biotechnology, 36(4): 307-309.

Keeves, G., Westphal, J. D., \& McDonald, M. L. 2017. Those closest wield the sharpest knife: How ingratiation leads to resentment and social undermining of the CEO. Administrative Science Quarterly, 62(3): 484-523.
McKinsey Institute. 2015. How advancing women's equality can add 12 trillion to global growth. http://www.mckinsey.com/global-themes/ employment-and-growth/how-advancing-womens-equality-canadd-12-trillion-to-global-growth. Accessed January 2018.

Paris, L. D., Howell, J. P., Dorfman, P. W., \& Hanges, P. J. 2009. Pre-

ferred leadership prototypes of male and female leaders in 27 countries. Journal of International Business Studies, 40(8): 13961405.

World Bank. 2019. Women, Business, and the Law. www.worldbank. org. Accessed 1 July 2019.

Amanda Budde-Sung (amanda.budde-sung@usafa.edu) is a Senior Lecturer in International Business at the University of Sydney, and is joining the Management Department at the U.S. Air Force Academy. She is the current President of the Women in the Academy of International Business. Dr. Budde-Sung has a Ph.D. in International Management and an MBA from the University of Hawaii, and a B.A. in Economics and Government from Smith College. Her research focuses on cross-cultural business ethics, with an emphasis on gender and history.

Amanda Bullough (bullough@udel.edu, www.linkedin.com/in/ amanda-bullough/) is an Associate Professor of Management and Global Leadership, and $\mathrm{C} 0$-Director and $\mathrm{Co}$-founder of the Women's Leadership Initiative, at the University of Delaware. She is a Past-President of the Women in the Academy of International Business. Dr. Bullough has a Ph.D. in Management \& International Business and an M.A. in International Studies, from Florida International University, and a B.S. in Marketing from the University of South Florida.

Tugba Kalafatoglu (tk@drentrepreneur.com) is a Research Fellow at OEME ESADE Business School. Her research and teaching include strategy, women entrepreneurship, international entrepreneurship \& business, social entrepreneurship, research methods. She is an international entrepreneur and advisor to governments, international companies, and academia. Dr. Kalafatoglu has a Ph.D. in Management \& International Entrepreneurship and a MRes from ESADE Business School, and a MALS from Georgetown University, and BA with Honors from the University of Nebraska at Omaha.

Fiona Moore is Professor of Business Anthropology at Royal Holloway, University of London. She received her doctorate from Oxford University, where she studied at the Institute for Social and Cultural Anthropology. Her research on identity in German multinational corporations has been published in the Journal of International Business Studies among others. She has written a monograph on German expatriates, with a second forthcoming monograph on Taiwanese elite labour migrants. More information is available at www.fiona-moore.com. 